\title{
The Causes, Prevalence And The Ravaging Corollaries Of Illegal Cross Border Trades (ICBTs) On Nigeria's Economy
}

\author{
Sunday Ojonugwa Ameh, Ph.D \\ Department of Sociology \\ Federal University, Wukari \\ Labar Nanloh Danjuma \\ Post Graduate Student, Department of Sociology \\ University of Abuja \\ Cyril 0. Ugwuoke, Ph.D \\ Department of Sociology and Anthropology \\ University of Nigeria, Nsukka \\ Cletus A. Lanshima, PhD \\ Directorate of Open and Distance Education \\ National Universities Commission
}

\begin{abstract}
This study elucidate the causes, prevalence and ravaging corollaries of Illegal Cross Border Trades ( ICBTs ) on the Nigerian economy with a view to proffering workable solutions. The study is anchored on the broken window theory. A sample size of $\mathbf{7 5}$ respondents was arrived at using Taro Yamane's formula and to ensure greater representation of the sample relative to the population, proportionate stratified random sampling technique was used for the selection of respondents. Quantitative data were obtained from the 75 selected respondents who were Nigeria Customs Service staff and who resides in Illela and Sabon-Birni border areas. These areas are in Sokoto State of Nigeria but share boundary with Niger Republic. Data collected were analyzed in line with study objectives and research hypotheses, using descriptive and inferential statistics at 0.05 level of significance. Findings revealed that though policies and programmes tailored along the line of curbing and ameliorating smuggling are made yearly, the rate of ICBTs continue to increase. Reasons for this include preference for foreign goods, craze for cheaper prices of goods, connivance between smugglers and some security personnel, paucity of border security. It was also found that the rate of ICBTs in the studied areas and by projection the nation is on the high side, thus contributing enormously to the receding economy. The study recommended among other things that a threesome relationship between Nigeria Customs Service, traditional elites and local settlers should be developed or built into government policies for curbing ICBTs; there should be a continuous orientation and re-orientation of the people by government agencies and other stakeholders; government increase employment opportunities and reduction in poverty rate; and government should be apt in carrying out statutory responsibilities.
\end{abstract}

Keywords: Border, Illegal Cross Border Trade, Security personnel, Smugglers, Threesome relationship.

\section{INTRODUCTION}

Illegal Cross Border Trades (ICBTs) commonly referred to as Smuggling is not a recent contributor to socio-economic problems across sovereign frontiers. Smugglers are deviants 
who are awful, brutal and consciously flout nation's import and export policies across international borders. According to Fortey (2008), smuggling has a long and controversial history, probably dating back to the first time duties were imposed on goods. In Britain for instance, smuggling first started in the late $16^{\text {th }}$ century when wool was smuggled into the country. Smuggling later became economically significant at the $17^{\text {th }}$ century, under the pressure of high excise taxes. The high rates of duty levied on tea and also wine, spirit, and other luxury goods coming in from mainland (Europe) at that time made clandestine import of such goods and evasion of the duty a highly profitable venture for impoverished fishermen and seafarers. Preventing illegal entry and export of goods into any jurisdiction has over time attracted enormous attention. This, according to Blum (2014) remains the major challenges confronting a good number of Africa countries. "Causal observations in the countries themselves, however, reveal that informal cross-border trade is thriving almost everywhere in Africa" (Benjamin, Golub \& Aly Mbaye, 2015). The past few years have been characterised by a significant increase in global criminal activities, among which are smuggling, money laundering, trade in organs and trafficking in human / human parts, counterfeit medicines, arms trafficking etc. (Luna, 2008).

Similarly, Ortuno (2009) reported that trans-national border smuggling pose enormous threat to global peace and security. Thus, the global trendy practices of independence between states and removal of border barriers, along socio-economic, cultural and political alliance, fosters the activities of transnational smugglers. This has a number of devastating consequences, such as: unemployment, fall in both volume and price of exports, drop in remittances, reduced direct foreign investment and downward tourism. In addition, insecurity may lead to proliferation of fire arms, indolent future generation and poor health due to influx of fake and substandard medicines.

Regarding Nigeria, ICBTs and anti - ICBTs operations have been in place even before the customs service was established in 1891, and still exist. The customs and excise preventive service was made up of two divisions. These are: the Maritime and Preventive. While the maritime division is responsible for the collection of import and export duties, alongside other related matters, the preventive division performs the function of enforcement which include prevention (anti-ICBTs) as well as arrest and prosecution of smugglers. Over times, Nigeria Customs Service had to contend with the arduous task of curtailing and possibly eradicating the anti- economic cankerworm generally referred to as smuggling (Ango, 1998). In general, the statutory functions of Nigeria customs service would include, but not limited to the following: The collection of, and accounting for, revenues such as Import duties, Export duties, excise duties, Taxes and other levies, the suppression of smuggling by enforcing Antismuggling operations, generating statistics for planning and budgetary purposes, collection and collation of statistical data on domestic production and international trade to support government planning, monitoring of foreign exchange utilization, engaging in research and planning, implementing government fiscal policies, enforcing the implementation of government industrial incentives for industrial development, processing of Import manifests, licensing and registration of Customs Agents, registration and designation of revenue collecting banks, working in collaboration with other government agencies in all approved ports and border stations, maintaining and enforce security functions through the border, and the ports, providing advice on inputs and suggestions towards the development of National trade, facilitating trade by enforcing the implementation of the provision of government's industrial incentives and direct foreign investment, protecting the Nigerian society through control of cargoes and goods entering, transiting or exiting Nigeria. In particular, the Nigeria Customs supports the combat of: Infraction to Intellectual Property Rights. (IPR), illegal commercial activities and illicit goods like import of fake and substandard goods, trafficking in 
illicit drugs, Illegal trade in Arms \& Ammunition, money laundering, illegal trade in cultural artifacts (Customs and Excise Management Act (CEMA), 1958).

Year after year, the government rolls out policies and programmes to curb the menace of smuggling in Nigeria, yet it had defied solution. Preference for foreign goods, craze for cheaper prices of goods, connivance between smugglers and some security personnel, unemployment, paucity of border security, preference for smuggling by border communities and so many others reasons made smuggling a serious threat to the economy of the country (Nwolise \& Okunade, 1987). Similarly, Imobighe (1990) assert that smuggling clearly destroys the local economy and exacerbates poverty in the country as manifested by the closure of local industries, decline in agricultural production, uncompetitive agricultural products, loss of jobs, loss of government revenues, heightened corruption in the bureaucracy and risks in consumer welfare. To other scholars, the likely problems of smuggling includes: threat to national security (Nwolise \& Okunade, 1987), Loss of government revenue (Ango, 1998), death of local industries (Chowghury, 2010; Ogah, 2015; Okoiye \& Adebisi, 2016), distortions of market prices (Akano, 1986) and Unemployment due to unfair competition leading to collapse of local industries.

The challenges posed by ICBTs often hold back the growth and development of countries, Nigeria not excluded. It is based on this premise, that the research elucidates the causes, prevalence and ravaging corollaries of ICBTs on the Nigeria economy with a view to proffering workable solutions.

\section{THEORETICAL ORIENTATION}

This study was anchored on the broken window theory by James Q. Wilson and George L. Kelling. The duo introduced the theory in 1982. It was further popularized in the 1990s by William Bratton and Mayor Rudy Giulliani. The theory focuses on proactive mitigatives measures deviance. If applied could help nip in the bud smaller deviation on time before it escalate hence, preventing devastating consequences. Wilson and Kelling (1982) submitted that:

Untended behaviour also lead to the breakdown of community controls. A stable neighbourhood of families who care for their homes, mind each other's children and confidently frown on unwanted intruders can change, in a few years or even a few months, to inhospitable and frightening jungle. A piece of property is abandoned, weeds grow up, a window is smashed. Adults stop scolding rowdy children, the children emboldened, become more rowdy. Families move out, unattached adults move in. teenagers gather in front of the corner store. The merchant asks them to move, they refuse, and fights occur, litter accumulates. People start drinking in front of the grocery; in time, an inebriate slumps to the sidewalk and is allowed to sleep it off. Pedestrians are approached by panhandlers. At this point it is not inevitable that serious crime will flourish or violent attacks on strangers will occur (p.3).

This submission clearly $\mathrm{x}$ - rayed the situation at border communities. It is likely, that border communities once experienced orderliness and communal co-existence probably before and shortly after routing trans-border trade, whether legal or illegal. However, the focus of this work is on elucidating the role of the border community's dwellers in creating fertile ground for smugglers through conscious and unconscious behaviours. In line with the submission of Wilson and Kelling, such intended or unintended behaviour endanger the future of the community. The communities become lodge and dumping ground for deviants, hence graduating from simple crimes to a more complex and devastating crime hotspot. 
In addition, the broken window theory asserts that "though citizens can do a great deal; the police are plainly the key to order-maintenance" (Wilson \& Kelling, 1982 p.9). The relevance of the community and constituted authority or agent of order, which in this case falls heavily on the customs service, in preventing and controlling smuggling are inseparable. Both are important stakeholder in the fight against ICBTs. However, the customs service and other law enforcement agencies, have enormous task to accomplish. In essence, a broken border community or country can be restored to the state of order when citizens sees themselves as stakeholders, provide relevant support to constituted authorities and the constituted authorities performs her duties judiciously.

Drawing from these submissions, the following research hypotheses guided the study:

1. Effective collaboration of citizens and Nigeria Customs Service (NCS) can asphyxiate ICBTs in Nigeria.

2. Un-throttled ICBTs contribute severely to the melting-down of Nigeria economy.

\section{METHODOLOGY}

This study was conducted in Illela and Sabon-Birni Local Government Areas in Sokoto State. They are located in the South Eastern and South Western parts of Sokoto State respectively. Illela and Sabon - Birni are selected for this study because they are border areas, sharing common boundary with Niger Republic. Although, Security agencies like National Drug Law Enforcement (NDLEA), Nigeria Police Force (NPF), Plant Quarantine, Nigeria Immigration Service (NIS) among others are visible in these border areas, staff of the NCS of these border areas were essentially targeted because they are statutorily responsible for mitigating ICBTs.

A sample size of 75 respondents was arrived at using Yaro Yamane's formula for calculating sample size. To ensure greater representation of the sample relative to the study population, the proportionate stratified random sampling techniques was used for the selection of respondents. Table 1 presents detailed breakdown of the population and sample size of the study. 
Table 1: Distribution of customs officers in Illela and Sabon-Birni border area

\begin{tabular}{|l|l|c|c|}
\hline \multicolumn{1}{|c|}{ Cadre } & \multicolumn{1}{|c|}{ Rank } & $\begin{array}{c}\text { No of } \\
\text { Officers }\end{array}$ & $\begin{array}{c}\text { Sample size } \\
\text { proportionate } \\
\text { representation } \\
\mathbf{1 2 \%}\end{array}$ \\
\hline Comptroller & Assistant Comptroller - Comptroller & 6 & 1 \\
\hline Superintendent & Assistant Superintendent II - Chief Superintendent & 120 & 15 \\
\hline Inspector & Assistant inspector - Chief Inspector & 140 & 17 \\
\hline $\begin{array}{l}\text { Customs } \\
\text { Assistant }\end{array}$ & Customs Assistant III - Chief Assistant & 184 & 22 \\
\hline TOTAL & & $\mathbf{4 5 0}$ & $\mathbf{5 5}$ \\
\hline
\end{tabular}

\begin{tabular}{|l|l|c|c|}
\hline \multicolumn{1}{|c|}{ CADRE } & \multicolumn{1}{|c|}{ RANK } & $\begin{array}{c}\text { No Of } \\
\text { Officers }\end{array}$ & $\begin{array}{c}\text { Sample size } \\
\text { proportionate } \\
\text { representation } \\
\mathbf{1 7 \%}\end{array}$ \\
\hline Comptroller & Assistant Comptroller - Comptroller & 2 & 1 \\
\hline Superintendent & Assistant Superintendent II - Chief Superintendent & 30 & 4 \\
\hline Inspector & Assistant inspector - Chief Inspector & 56 & 7 \\
\hline $\begin{array}{l}\text { Customs } \\
\text { Assistant }\end{array}$ & Customs Assistant III - Chief Assistant & 62 & 8 \\
\hline TOTAL & & $\mathbf{1 5 0}$ & $\mathbf{2 0}$ \\
\hline Sample Size & & & $\mathbf{7 5}$ \\
\hline
\end{tabular}

Source: Field survey (2016).

Quantitative data were obtained from the 75 selected respondents who were Nigeria Customs Service Staff, and reside in Illela and Sabon-Birni border areas, because the pre-test indicated that $70 \%$ of staff had resided in the affected areas for an average of three - five years. Approval for the study was obtained from the department of Criminology and Security Study, and Research Ethics Committee of Salem University Lokoja, Kogi State as well as from the staff of Nigeria Customs Service of selected areas. The purpose of the study was clearly related to the respondents and anonymity as well as confidentiality was assured. Through the use of structured and open ended questionnaire data were collected and analysed in line with the study objectives and research hypotheses, using descriptive and inferential statistics at 0.05 level of significant. 


\section{RESULTS}

Table 2: Bio-Data of Respondents

\begin{tabular}{|l|lcc|}
\hline Characteristics & Categories & Frequency & Percent \\
\hline \multirow{5}{*}{ Gender } & Male & 60 & 80.0 \\
& Female & 15 & 20.0 \\
\cline { 2 - 4 } & Total & $\mathbf{7 5}$ & $\mathbf{1 0 0 . 0}$ \\
\hline \multirow{5}{*}{ Marital Status } & $21-30$ & 30 & 40.0 \\
& $31-40$ & 20 & 26.7 \\
& $41-50$ & 15 & 20.0 \\
& 51 and above & 10 & 13.3 \\
\cline { 2 - 4 } & Total & $\mathbf{7 5}$ & $\mathbf{1 0 0 . 0}$ \\
\hline \multirow{5}{*}{ Educational Qualification } & Single & 25 & 33.3 \\
& Married & 35 & 46.7 \\
& Widowed/separated & 15 & 20.0 \\
\cline { 2 - 4 } & Total & $\mathbf{7 5}$ & $\mathbf{1 0 0 . 0}$ \\
& $\leq$ WAEC/GCE & 25 & 33.3 \\
& OND/HND & 20 & 26.7 \\
& First Degree & 20 & 26.7 \\
& Post Graduate & 10 & 13.3 \\
\cline { 2 - 4 } & Total & $\mathbf{7 5}$ & $\mathbf{1 0 0}$ \\
\hline \multirow{5}{*}{ Service/ Years of residence } & $1-10$ years & 30 & 40.0 \\
& $11-20$ years & 35 & 46.7 \\
& 21 years and above & 10 & 13.3 \\
\cline { 2 - 4 } & Total & $\mathbf{7 5}$ & $\mathbf{1 0 0 . 0}$ \\
\hline
\end{tabular}

Source: Field Survey (2016).

Table 2 indicates that $80.0 \%$ of the respondents were male while just $20.0 \%$ of the respondents were female. The variation indicates the ratio of male to female in the study population. Respondents distribution across age, revealed that majority $(40.0 \%)$ of the respondents falls under age 21 - 30, this affirmed the distribution presented in table 1 . This infer that NCS at the study areas apart from being bottom heavy in terms of ranks, she is also bottom heavy in terms of age. Consequently, while $26.7 \%$ and $20.0 \%$ represents age $31-40$ and $41-50$ respectively, age 51 and above constituted $13.3 \%$ in the distribution. Over one third $(46.7 \%)$ of the respondents were married, one third $(25.0 \%)$ were single and below one third $(20.0 \%)$ of the respondents were either separated from the spouse or loss their spouse to death. The distribution also reveals that all of the respondents have at least WAEC or GCE certificate. Commendably, $13.3 \%$ and $26.7 \%$ had post graduate and first degree as their highest formal educational qualification. Finally, the distribution indicates that the respondents have spent adequate time in service and had adequate experience to make the solicited information reliable. $13.3 \%$ and $46.7 \%$ constituted those that have spent 21 years and above and $11-20$ years in service respectively. 


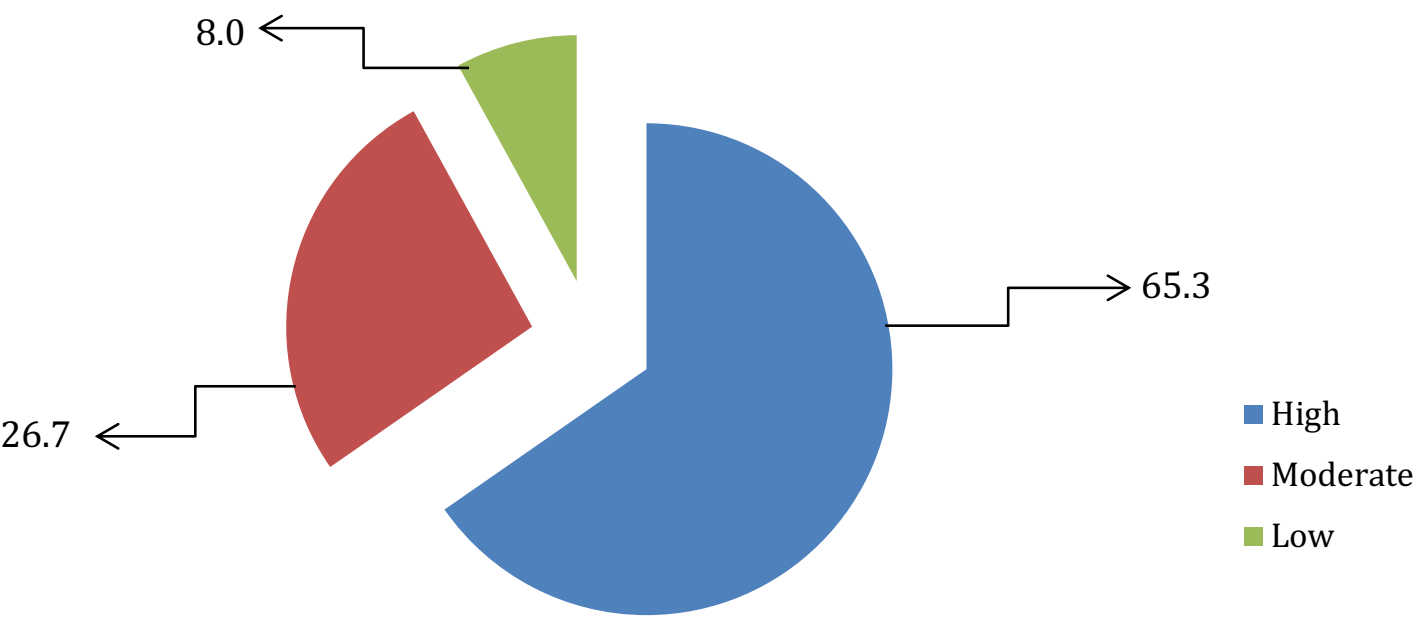

\section{Figure 1: Rate of ICBTs through Illela and Sabon - Birni Borders}

\section{Source: Field survey (2016)}

Figure 1 shows respondents assessment of the rate of ICBTs through the selected borders. slightly over two third of the respondents (65.3\%) rated high ICBTs through Illela and SabonBirni borders. Less than one third (26.7\%) of the respondents indicated that ICBTs through these borders are moderate while relatively low $(8.0 \%)$ of the respondents indicate low rate of ICBTs through these borders. the findings indicated that ICBTs is not a mirage but a known practice. More so, that $65.3 \%$ of the respondents are in agreement of alarming high rate of ICBTs through the investigated borders.

Table 3: Effective collaboration of NCS and border settlers, and asphyxiation of ICBTs in Nigeria

\begin{tabular}{|c|c|c|c|c|c|c|c|}
\hline & \multicolumn{7}{|c|}{ Agreement on collaboration stifling ICBTs } \\
\hline & & Agree & Disagree & $\begin{array}{l}\text { Don't } \\
\text { know }\end{array}$ & $\begin{array}{l}\text { Pearson } \\
\text { Chi square }\end{array}$ & $\mathrm{df}$ & $\begin{array}{l}\text { Asymp Sig. } \\
\text { (2-sided) }\end{array}$ \\
\hline Rate existing & Very cordial & 0 & 7 & 2 & & & \\
\hline collaboration & Cordial & 4 & 14 & 0 & 55.899a & 4 & .000 \\
\hline $\begin{array}{l}\text { between NCS and } \\
\text { border settlers } \\
\text { against ICBTs }\end{array}$ & Not Cordial & 42 & 21 & 6 & & & \\
\hline
\end{tabular}

Source: Field survey (2016)

Table 3 indicate significant relationship between effective collaboration of NCS and border dwellers, and asphyxiation of ICBTs in the study area $\left(X^{2}\right.$ value $=55.899$ a, $\mathrm{df}=4$ and Asymp. Sig. $(2$ sided $)=.000)$. given that the Asymp value was less than $<0.05$, it therefore implies that when NCS and border settler communities member collaborate effectively, ICBTs will be stifled. 
Table 4: Relationship between un-throttled ICBTs and economic meltdown

Agreement to the negative influence of ICBTs on the economy

\begin{tabular}{llcccccc} 
& & Agree & Disagree & $\begin{array}{c}\text { Don't } \\
\text { Know }\end{array}$ & $\begin{array}{c}\text { Pearson } \\
\text { Chi square }\end{array}$ & df & $\begin{array}{c}\text { Asymp Sig. } \\
\text { (2-sided) }\end{array}$ \\
\hline Rate ICBTs' & Very High & 4 & 0 & 0 & & & \\
influence on & High & 9 & 0 & 0 & & & \\
economy & Moderate & 21 & 0 & 0 & $75.695^{\mathrm{a}}$ & 8 & .000 \\
& Low & 1 & 24 & 9 & & & \\
& Very low & 0 & 7 & 0 & & & \\
\hline
\end{tabular}

Source: Field survey (2016)

Show the relationship between un-throttled ICBTs and economic meltdown. The the result of $\mathrm{X}^{2}=75.695^{\mathrm{a}}, \mathrm{df}=8$ and Asymp Sig $(2$ sided $)=.000$, indicate a strong relationship between unthrottled ICBTs and economic meltdown of the study areas. Given that the Asymp value .000 is less than $<0.05$, implies that if illegal cross border trades are not prevented the economy of the affected areas or nation will experience steady decline.

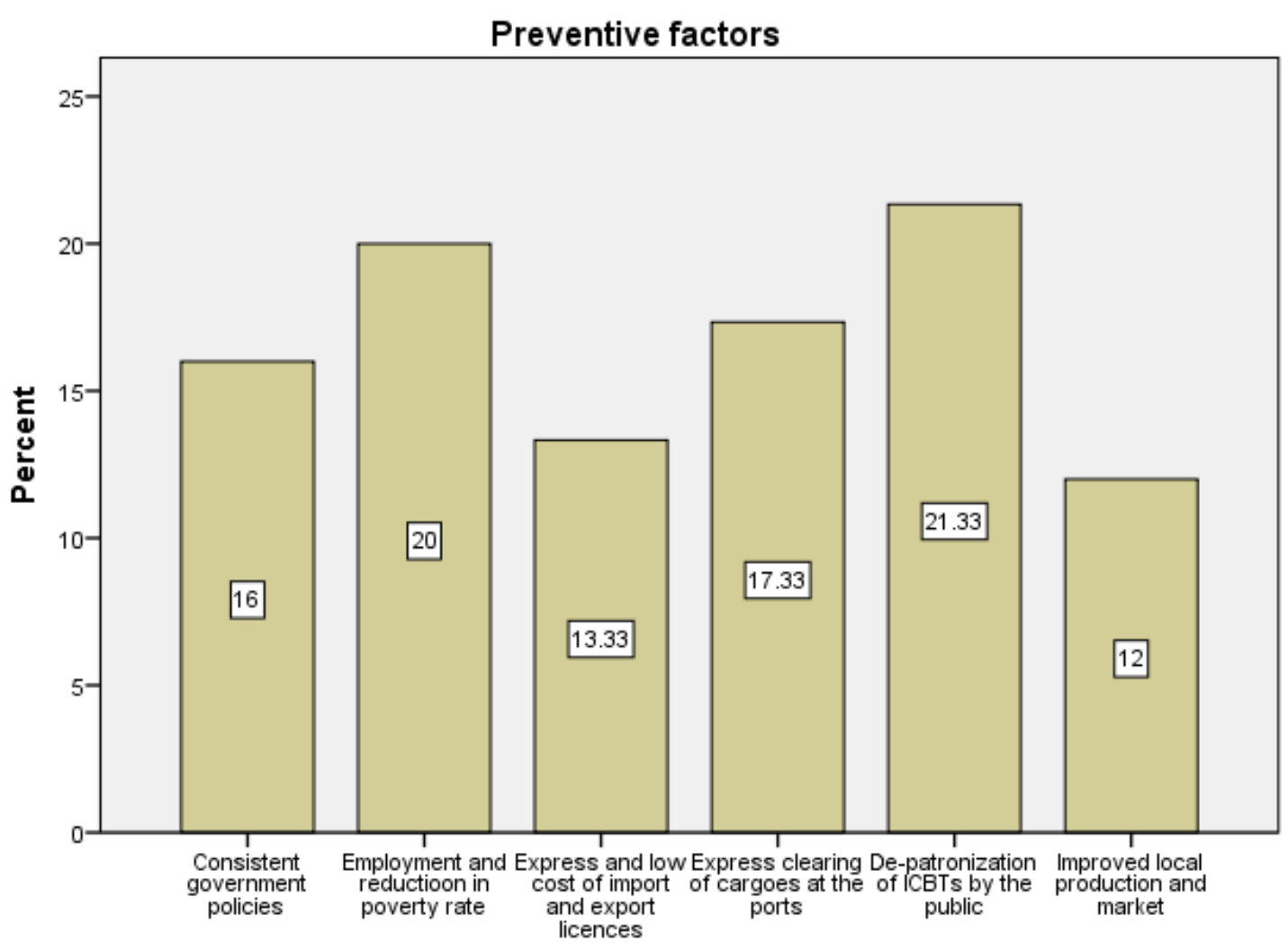

Flgure 2: Other ICBTs preventive factors

Figure 2 indicates other possible factors that can prevent ICBTs through and around the selected borders, aside effective enlightenment and collaboration between NCS and BS. Respondents were requested to indicate possible factors that could stifle ICBTs through the highlighted routes, though they were required to indicate numerous factors, their responses were scaled from $1-6$ and regrouped as indicated in figure 2. While $21.33 \%$ of the respondents indicated that the de-patronization of ICBTs by all stake holders will stifle ICBTs, 
closely followed are $20.0 \%$ and $17.33 \%$ of the respondents tilting toward government provision of lucrative jobs which will in-turn reduce poverty rate, and express clearing of cargoes at the ports respectively. Others are: $16.0 \%$ for consistent government policies, $13.33 \%$ for express and low cost charges on import and export licenses. Finally, 12.0 of the respondents indicated that the improvement on the quality of local products and market will stifle ICBTs. This implies that preventing or ameliorating ICBTs attracts the contribution of all stakeholders (the government, statutory agencies, BS and consumers, among others).

\section{Table 5: Logistic Regression outcome for degree of ICBTs on effective collaboration and Asphyxiation of ICBTs}

In order to ascertain the relationship between the asphyxiation of ICBTs on willingness of BS to collaborate with NCS and awareness of the ICBTs in the study areas, a logistic regression analysis was undertaken. It is important to note that the rate of ICBTs were considered as the critical variable and used to examine willingness to collaborate and asphyxiation of ICBTs in study areas.

\begin{tabular}{|c|c|c|c|c|c|c|c|}
\hline & & B & S.E & Wald & $\mathrm{df}$ & Sig & ExpB \\
\hline \multirow{4}{*}{$\begin{array}{l}\text { Rate ICBTs' } \\
\text { influence on } \\
\text { economy }\end{array}$} & $\begin{array}{l}\text { ICBTs } \\
\text { Awareness }\end{array}$ & -.385 & 17950.603 & .000 & 1 & 1.000 & .680 \\
\hline & $\begin{array}{l}\text { NCS \& BS' } \\
\text { Collaboration }\end{array}$ & 20.732 & 14705.519 & .000 & 1 & .999 & 1009180584 \\
\hline & Constant & -61.658 & 59716.063 & .000 & 1 & .999 & .000 \\
\hline & & \multicolumn{6}{|c|}{ Source: Field survey (2016) } \\
\hline
\end{tabular}

The result indicates that awareness of the alarming rate of ICBTs and its consequences $(\mathrm{B}=-$ .385 , wald $=.000, \mathrm{p}<0.05)$ and effective collaboration between NCS and BS' $(B=20.732$, wald $=.000, \mathrm{p}<0.05$ ) will contribute significantly in the study areas, given the ExpB .680 and 1009180584 respectively. Hence, in order to achieve significant asphyxiation of ICBTs in the awareness / sensitization efforts on the danger of ICBTs and likewise improvement on the collaboration of NCS and BS' in the prevention of ICBTs and apprehension of culprits.

\section{DISCUSSION AND RECOMMENDATIONS}

The study generally $x$-rayed the causes, prevalence and the ravaging corollaries of illegal cross border trades (ICBTs) on Nigeria's economy. The outcome of this study negates some of the popularly shared assertions on crime and development. More prominent, is the assertion that crime has negative and significant impact on the economic growth in the long run (Ahmad, Ali \& Ahmed, 2014). The study revealed that though studies indicate mathematical long run positive relationship between crime and economic growth, they failed to take into account the negligible deposits (NDs) from the act of crime. Such as the gradual breakage of law and order, increase dis-belief in constituted authority, fading away of morals and lawful ways of attaining success and the gradual decay of the nation's image in the eyes of the international community, among others. Because these NDs are not quantifiable they may not be considered when asserting the long run positive contribution of crime to development. The aforementioned NDs and more contributed to the un-throttledness of ICBTs, this invariably on the long run instead of contributing positively toward economic development resulted to nations economic meltdown.

Secondly, the study further exposes the high rate of ICBTs along the studied border areas. This finding corroborates Nwolise and Okunade's (1987) assertion, that year in year out, policies and programmes tailored along the line of curbing and ameliorating smuggling in Nigeria were presented by the government. Yet the rate of ICBTs continue to increase, due to preference for 
foreign goods, craze for cheaper prices of goods, connivance between smugglers and some security personnel, paucity of border security and so many more. These make ICBTs a serious threat to the economy of any country. inferring from above, ICBTs to a large extent will destroy the indigenous economy, enshrine poverty in the affected country by fostering closure of native small and medium scale industries, reduction in job creation and loss of jobs, decline in government revenue, and fading away of the competition in local agricultural products and finally, threat to national security due to increased appetite for illegal cheap product and recruitment of new illegal cross border traders as well as the professionalization of existing ones.

Thirdly, the finding negates one of the salient points projected by modernization theorists. These theorists often saw traditions as obstacles to economic advancement. Hence, suggesting violent, radical change for traditional societies (Lipset, 1967). However, the study revealed that radical shift from tradition and traditional elites involvement in stifling ICBTs contributed to the low rate of collaboration that existed between border settlers and NCS in stifling ICBTs or the development of mind your business form of relationship. In order to ensure notable progress in the fight against ICBTs a threesome relationship should be developed or built into government policies for curbing ICBTs. This implies, encouragement of positive collaboration among the NCS, traditional elites and local settlers in the fight against ICBTs.

Fourthly, the study identified possible solutions to the problem of ICBTs. In addition to the threesome relationship earlier discussed, the study in figure 2 identified six preventive factors. The factors in reducing order of impact are: (1) De-patronization of ICBTs by the public. Continuous orientation and re-orientation of the people by government agencies and other stakeholders is required to bring consumers, retailers and potential as well professional smugglers to a level of collective consciousness that considers consumption and trade of smuggled goods as injurious to self- first before all. (2) increase in employment opportunity and reduction in poverty rate. One of the attractions to the patronization or involvement in ICBTs is poverty or non-engagement in meaningful/lucrative job. Government as well as private investors should intensify effort in this light. (3) express clearing of cargoes at the ports. (4) consistent government policies and (5) express and low cost of import and export licensing. These three are inter-related. They required government aptness in carrying out statutory responsibilities. They represent the three Cs in curbing ICBTs: Consistency, Certainty and Celerity. These implies Consistent government policies; certainty in charges, import and export duties and finally, celerity in the clearing of cargoes at the ports. (6) the improvement of local production and market. This can provide helping hand to factor number two discussed above. An improved market, creates job and healthy competition among local industries hence, ensure standard, quality and economic growth. In addition, it provides hostile milieu for ICBTs.

\section{CONCLUSION}

ICBTs is not a recent problem in Nigeria, hence, its causes, prevalence and ravaging corollaries may have endured policies rolled out year after year to curb or stifle it. The rate of ICBTs in the studied areas and by projection the nation is on the high side, by implication contributing enormously to the receding economy. The long and steady practices of ICBTs have greatly contributed to the economic challenges confronting the nation currently. Though the reduction of the potency of local industries, decline jobs creation and increase in loss of jobs, increase in poverty rate, increase in illegal access to weapons and by extension crime and insecurity in the country are all associated with ICBTs, the nation is not completely helpless in the fight to surmount ICBTs. Discouraging mind your business approach by fostering threesome relationship and collective consciousness can sway ICBTs towards decline or gradual extinction. 


\section{ACKNOWLEDGEMENTS}

The authors acknowledge the contributions of individuals and corporate bodies that helped to facilitate the completion of this study. We are especially indebted to the staff of the Nigeria Customs Service in Illela and Sabon - Birni Border areas in Sokoto State, Nigeria.

\section{Refernces}

Akano, $\mathrm{O}$ (1986). The effects of smuggling on the protection of industries in Nigeria Ibadan; Nigerian Institute for social and Economic Research NISER.

Ahmed, A., Ali, S. \& Ahmed, N. (2014). Crime and economic growth in developing countries evidence from Pakistan. In Journal of Basic and Applied Scientific Research. 4(4)31-41.

Ango, SOG (1998). “ The Role of Nigeria Customs Service in the realization of vision 2010 spectrum books Ltd Ibadan 1998.

Benjamin, N., Golub, S. \& Aly Mbaye, A. (2015). Informal Cross Border Trade and Smuggling in West Africa. In Journal of Borderlands Studies. Volume 30. Issues 3.

Blum, C. (2014). Cross-Border Flows between Nigeria and Benin: what are the Challenge for (human) Security? Abuja, Nigeria: Friedrich-Ebert-Stiftung

Chowghury, F. L(2010) “Economics of smuggling” Wikipedia March 2016

Customs and Excise Management Act (CEMA)(1958). "Laws of the Federation of Nigeria (LFN), CAP 45 OF 2004" as amended.

Imobighe, T, A.(1990) "Doctrines for and threats to internal Security" in A, E EKOKO and M. A. Vogts (ed) Nigeria Defence Policy: Issues and Problems (Lagos Maltose press 1990).

Lipset, S. M. (1967). Education and entrepreneurship. Elites in Latin America. New York: Oxford University Press.

Luna,D. M.,(2008). Dismantling Illicit Networks and Corruption Nodes. From <http://www.13iacc.org/IACC work shops/workshop 6.2.> (Retrieved March 8, 2010).

Fortey, I. (2008). “The Seven most ingenious (and insane) SmugglingTechniques” pp583-922.

Nwolise, O.B. C and Okunade, B (1987). “Combating Smuggling in Nigeria”; Jato Publishing co. Ibadan.

Ogah (2015): “The Scourge of smuggling in Nigeria” Business and Maritime Magazine November, 2015.

Okoiye, O. E. \& Adebisi, K. F. (2016). Moderating effect of smuggling, bad character and negative ability of youths in Shali Boarder town, Oyo State Nigeria. In International Journal of Education, Learning and Development. Vol. 4, No. 2. Pp. $58-72$.

Ortuno,M. T., (2009). Cooperation and Shared Responsibility in the Global Fight Against Organised Crime in Particular Drug Trafficking, Illegal Arms Sales, Human Trafficking and Cross-Border Terrorism. DRAFTREPORT submitted to IDI Assembly of the Inter parliamentary Union and Related Meetings, General.

Wilson, J. Q. \& Kelling, G. I. (1982). The police and neighbourhood safety: Broken windows. In The Atlantic Monthly. March, 29-38. 